\title{
Glucose-transport-deficient mutants of Schizosaccharomyces pombe: phenotype, genetics and use for genetic complementation
}

\author{
Birgitta Milbradt and Milan Höfer
}

Author for correspondence: Milan Höfer. Tel: +49228 735545. Fax: +49 228735504 .

Botanisches Institut der Universität, Kirschallee 1 , D-53115 Bonn, Germany

\begin{abstract}
Glucose-transport-deficient mutants of Schizosaccharomyces pombe were obtained by treatment of wild-type cells $\left(972 h^{-}\right)$with $N$-methyl- $N^{\prime}$-nitro-Nnitrosoguanidine, and by selection of resulting mutants on gluconate medium containing 0.05\% 2-deoxy-D-glucose (2DG). One mutant, designated YGS-B22, was unable to grow on D-glucose and/or D-fructose as a carbon source (GIC/Fru'), and was resistant to 2DG; hence, none of the three sugars was taken up by the mutant cells. The hexokinase activity in the wild-type and the mutant cells was equal. Genetic purification of YGS-B22 by back-crossing with a leucine-auxotrophic mutant and the wild-type resulted in two strains: YGS-4, with reduced 2DG resistance, and YGS-5, which had lost 2DG-resistance. YGS-5 grew in D-glucose-containing media, albeit very slowly. No measurable sugar uptake was detectable in either of the two mutants within the $1 \mathrm{~h}$ test interval. Tetrad analyses proved a Mendelian segregation of growth on Dglucose and leucine auxotrophy. However, 2DG resistance did not co-segregate with the Gld/Fru- phenotype, indicating that the transport deficiency and 2DG resistance characters are not encoded on the same genomic locus. Using a genomic bank of Sch. pombe, two transformants, YGS-5-G7 and YGS-5-G12, were found which had regained the wild-type growth and transport phenotype by complementation. Correspondingly, both D-glucose uptake and 2DG accumulation were restored in the transformed strains. Restriction analysis and Northern blots suggested that the $\mathbf{G 7}$ genomic fragment and the $4.1 \mathrm{~kb}$ Sall restriction fragment of the $\mathrm{G12}$ genomic fragment both contain a complete structural symporter gene.
\end{abstract}

Keywords: yeast, glucose transport mutants, genetic complementation, glucose symporter gene, Schizosaccharomyces pombe

\section{INTRODUCTION}

The fission yeast Schizosaccharomyces pombe takes up hexoses in symport with $\mathrm{H}^{+}$(Höfer \& Nassar, 1987). The transport across the plasma membrane is rate-limiting for utilization of both D-glucose and D-fructose. Hence, only non-metabolizable glucose analogues, such as 2-deoxy-Dglucose (2DG) and glucosamine, are significantly accumulated in the cytosol. The glucose symporter of $S c h$. pombe displays higher affinity to $2 \mathrm{DG}\left(K_{\mathrm{T}}=2 \mathrm{mM}\right)$ than to Dglucose $\left(K_{\mathrm{T}}=15 \mathrm{mM}\right)$, which is the richest carbon source

Abbreviation: 2DG, 2-deoxy-D-glucose.

This paper is dedicated to Augustin Betz, colleague and scholar, on the occasion of his 75 th birthday. for cell growth. The maximum transport velocity for $\mathrm{D}-$

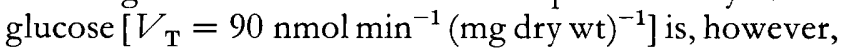
about three times higher than that for $2 \mathrm{DG}$ (Höfer \& Nassar, 1987).

The challenging goal in membrane transport research is the isolation of a particular transport protein and its functional reconstitution in artificial phospholipid vesicles. The main problem of this strategy is the identification of the transport protein in a mixture of solubilized membrane proteins, especially if the protein of interest belongs to a constitutive transport system. However, this problem can be circumvented by identifying the gene which encodes the transport protein, and by its in vitro expression. Our strategy in cloning the glucose symporter has therefore been to screen a genomic 
gene bank of $S c h$. pombe in a yeast/bacterial shuttle vector (Beach $e t$ al., 1982) for the transport structural gene by genetic complementation (Rose, 1987).

This report deals with isolation and genetic characterization of $S c h$. pombe mutants deficient in glucose transport and their use in identifying genomic DNA fragment(s) encoding the glucose symporter. The isolation of glucosetransport-deficient mutants was made possible by an earlier finding that D-gluconate, as the sole carbon source, is taken up in $S c h$. pombe by a specific transport system different from that for D-glucose (Hoever et al., 1992). Preliminary results of this work have been published (Milbradt \& Höfer, 1991; Milbradt et al., 1993).

\section{METHODS}

Organism and growth. The mutants described were obtained from the wild-type strain of the fission yeast Schizosaccharomyces pombe $972 \mathrm{~h}^{-}\left(\mathrm{NCYC} 1827 \mathrm{~h}^{-}\right)$. The strains used for crossing experiments were: the wild-type strain $975^{+}\left(\mathrm{NCYC} 1828 \mathrm{~h}^{+}\right)$ and the auxotrophic mutant leu $1-32 b^{+}$. For genetic complementation a mutant deficient in the early meiotic phase, mat2B102 lys 1-131, was used. All four strains were kindly provided by P. Munz, University of Bern, Switzerland. For mutagenesis, transport experiments, hexokinase assay, transformation, and plasmid preparation, the particular yeast strain was grown aerobically in synthetic minimal medium (MM) at $30^{\circ} \mathrm{C}$ (Gutz et al., 1974) containing $4.7 \%(\mathrm{w} / \mathrm{v}) \mathrm{D}$-gluconate (potassium salt) as sole carbon source (MMG). When required, the liquid growth media were supplemented with $0.5 \mathrm{~g}$ 2-deoxy-D-glucose $\mathrm{I}^{-1}(\mathrm{MMG}+2 \mathrm{DG})$ and/or $10 \mathrm{mg}$ leucine $\mathrm{l}^{-1}(\mathrm{MMG}+\mathrm{L})$. Prior to autoclaving, the $\mathrm{pH}$ of the media was adjusted to $4 \cdot 5$. Cells were harvested in the mid-exponential phase. To prepare solid minimal media, $2 \%(\mathrm{w} / \mathrm{v})$ agar was added (MMA). The first step of screening of mutants and transformants was performed at $30^{\circ} \mathrm{C}$ on three different solid screening media: MMAG medium supplemented with $0.5 \mathrm{~g} \mathrm{2DG} \mathrm{l}^{-1}$ (MMAG+2DG) and MMA media in which $3 \%(\mathrm{w} / \mathrm{v})$ D-glucose (MMAGl) and $/$ or $3 \%(\mathrm{w} / \mathrm{v})$ D-fructose (MMAFr) substituted D-gluconate as the carbon source. Sporulation was induced by incubation of yeast cells on malt extract agar plates $(1 / 2 \mathrm{MEAG}:$ malt extract, $15 \mathrm{~g} \mathrm{l}^{-1}$; D-gluconate, $23.5 \mathrm{~g} \mathrm{l}^{-1}$; and agar, $20 \mathrm{~g} \mathrm{l}^{-1} ; \mathrm{pH} \mathrm{5.9)} \mathrm{at}$ $25^{\circ} \mathrm{C}$. Spore germination was carried out at $30^{\circ} \mathrm{C}$ on yeast extract agar plates (YEAGGl: yeast extract, $5 \mathrm{~g} \mathrm{l}^{-1}$; Dgluconate, $47 \mathrm{~g} \mathrm{l}^{-1}$; D-glucose, $6 \mathrm{~g} \mathrm{l}^{-1}$; and agar, $20 \mathrm{~g} \mathrm{l}^{-1}$; $\mathrm{pH} 5.9$ ) enriched with the appropriate supplements (leucine or lysine) where required; the supplement of D-glucose was necessary to initiate germination. Another rich medium used was YEAG, with the same composition as YEAGGl but without D-glucose.

Plasmids were propagated in Eschericbia coli $\mathrm{DH} 5 \alpha$ [end $A 1$ bsdR17 $\left(\mathrm{r}_{\mathrm{k}}^{-}, \quad \mathrm{m}_{\mathrm{k}}^{+}\right)$supE44 $\operatorname{rec} A 1 \operatorname{gyr} A 96 \operatorname{rel} A 1 \operatorname{deo} \mathrm{R}$ $\Delta($ lacZY A-argF $) U 196$ thi-1 $\phi 80 \mathrm{~d}$ lacZ $\Delta \mathrm{M} 15 \mathrm{~F}^{-}$] grown in Luria broth (Lennox, 1955) in the presence of $100 \mathrm{mg}$ ampicillin $\mathrm{l}^{-1}$. The strain was kindly supplied by B. Persson, University of Umeå, Sweden.

Mutagenesis. Wild-type cells of $S c h$. pombe $972 \mathrm{~h}^{-}$were treated with $N$-methyl- $N^{\prime}$-nitro- $N$-nitrosoguanidine $\left(3 \mathrm{mg} \mathrm{ml}^{-1}\right)$ for $20 \mathrm{~min}$ in $0.2 \mathrm{M}$ potassium acetate buffer ( $\mathrm{pH} 5)$ at $30^{\circ} \mathrm{C}$. Mutant enrichment was achieved by a modification of the procedure of Megnet (1965a) in which the culture media contained $0.5 \mathrm{mg}$ $2 \mathrm{DG} \mathrm{ml}^{-1}$ and the incubation time in batch culture (containing gluconate) was extended to $2 \cdot 5 \mathrm{~d}$. Culture aliquots were plated on selection plates (MMAG $+2 \mathrm{DG})$ to form colonies $(10-15 \mathrm{~d}$ growth at $30^{\circ} \mathrm{C}$ ) which were further tested for potential transport-deficient phenotype by replica plating on the screening plates $\left(3 \mathrm{~d}\right.$ growth at $30^{\circ} \mathrm{C}$ ).

Transport experiments. The uptake of $\mathrm{D}-\left[{ }^{14} \mathrm{C}\right]$ glucose and $\mathrm{D}-$ $\left[{ }^{14} \mathrm{C}\right]$ fructose was measured in supernatants of reaction suspensions as described by Milbradt \& Höfer (1990). The accumulation of 2-deoxy-D- $\left.{ }^{3} \mathrm{H}\right]$ glucose was determined by analysis of hot water cell extracts as reported by Niemietz et al. (1981).

Enzyme assay. The hexose-ATP-kinase activity was assayed by the procedure used earlier (Mahlberg et al., 1985). The cell-free extracts were prepared as described by Ciriacy (1976); the hexose 6-phosphate was determined enzymically (Lang \& Michal, 1974)

Genetic methods. Mutants were crossed with the auxotrophic Sch. pombe strain leu1-32 $b^{+}$to introduce a $\mathrm{Leu}^{-}$marker for transformation experiments. The resulting double mutants were back-crossed three times with the wild-type $975 \mathrm{~h}^{+}$using freespore analysis as described by Gygax \& Thuriaux (1984). After each crossing the mating type of the progeny was also determined. Tetrad analysis was performed by micromanipulation of the asci (Gutz et al., 1974). Stable diploid cells for genetic complementation were obtained by crossing the transport-deficient mutants with the mat2-B102 lys 1-131 strain and identifying diploid colonies by Phloxin B (Gutz et al., 1974).

Transformation. E. coli $\mathrm{DH} 5 \alpha$ cells were transformed according to the methods of Maniatis et al. (1982). Sch. pombe cells were transformed by the method of Ito et al. (1983) and Heyer $e$ al. (1986) except that $50 \mu \mathrm{g}$ salmon sperm DNA was added together with the DNA to be transformed.

Complementation and plasmid recovery. Recombinant plasmids complementing the mutant deficiency were identified by transformation of mutant cells with a genomic gene bank, CV13, which was kindly supplied by P. Nurse, University of Oxford, UK. The $\mathrm{CV}^{13}$ genomic library was constructed by partial digestion of $S c h$. pombe nuclear DNA with $S a u 3$ A and ligation in the BamHI restriction site of the yeast/bacterial shuttle vector YEp13 (Beach et al., 1982). Leu ${ }^{+}$transformants were detected on MMAG plates. All transformants were tested for their ability to grow on D-glucose and $\mathrm{D}$-fructose by replica plating on the screening plates. Plasmids from complemented transformants with wild-type phenotype were recovered by extracting total DNA as described by Moreno et al. (1991) and transforming E. coli $\mathrm{DH} 5 \alpha$.

Restriction analysis. DNA manipulation was performed using standard methods (Maniatis et al., 1982). Plasmid DNA was purified by equilibrium centrifugation in caesium chloride/ ethidium bromide density gradients. Genomic DNA inserts were excised and further digested by treatment with appropriate endonucleases. DNA fragments were analysed after denaturation at $68{ }^{\circ} \mathrm{C}$ by electrophoresis in $0.8 \%$ agarose gels in Tris/acetate buffer ( $\mathrm{pH} 8$ ). Enzymic reactions were carried out according to the protocols of the enzyme manufacturer (Boehringer). When required, DNA fragments were purified using the Quiaex-Kit obtained from Diagen.

RNA analysis. Total yeast RNA was extracted as described by Moreno et al. (1991). Samples of the total RNA preparations were resolved in $1 \%(\mathrm{w} / \mathrm{v})$ agarose gels containing formaldehyde and transferred to nitrocellulose membranes according to Maniatis et al. (1982). For hybridization and detection of hybridization products the non-radioactive DNA labelling kit of Boehringer was used.

Chemicals. 2DG was from Calbiochem, $N$-methyl- $N^{\prime}$-nitro- $N$ - 
Table 1. Growth phenotype of the wild-type and the 2DG-resistant colonies

MMAGI, MMAFr, MMAG and MMAG +2DG: screening agar plates with D-glucose, D-fructose,

D-gluconate and D-gluconate $+2 \mathrm{DG}$ as carbon source, respectively. WT, wild-type; wanted, predicted

phenotype of mutant required. For further details see Methods.

\begin{tabular}{|lccccc|}
\hline Group & MMAG1 & MMAFr & MMAG & MMAG +2DG & Colonies \\
\hline WT & ++++ & ++++ & +++ & - & \\
Wanted & - & - & +++ & +++ & \\
\hline I & - & - & +++ & +++ & 26 \\
II & - & - & +++ & + & 7 \\
III & - & - & +++ & - & 2 \\
\hline
\end{tabular}

nitrosoguanidine from Boehringer, and the radiolabelled monosaccharides from Amersham-Buchler. All other compounds were of reagent grade, from Merck.

Table 2. Hexose-ATP-kinase activity of the wild-type and the mutant YGS-B22

For analytical procedures see Methods.

\begin{tabular}{|ccc|}
\hline Substrate & $\begin{array}{c}\text { Hexose-ATP-kinase } \\
\text { [nmol } \text { min }^{-1} \\
\text { (mg protein })^{-1} \text { ] }\end{array}$ \\
\cline { 2 - 3 } & Wild-type & YGS-B22 \\
\hline D-Glucose & $322 \pm 55$ & $345 \pm 23$ \\
D-Fructose & $510 \pm 48$ & $523 \pm 18$ \\
D-Gluconate & $23 \pm 4$ & $20 \pm 4$ \\
\hline
\end{tabular}

\section{RESULTS AND DISCUSSION}

\section{Mutagenesis and screening of mutants}

In four independent mutagenesis experiments, 1642 2DGresistant $\left(2 \mathrm{DG}^{\mathbf{R}}\right)$ colonies were isolated. The mutants were tested for their potential transport-deficiency phenotype by growth on screening plates containing either D-gluconate (MMAG), D-gluconate $+0.05 \% 2 \mathrm{DG}$ (MMAG + 2DG), D-glucose (MMAGl) or D-fructose (MMAFr) as carbon source (Table 1). Twenty-six mutants displayed resistance to $2 \mathrm{DG}$ when grown on $\mathrm{D}$-gluconate and no growth with either D-glucose or D-fructose. To eliminate metabolic mutants, mostly deficient in the hexose-phosphorylation capacity, which frequently occur after selection with 2DG (Megnet, 1965b), both the activity of the hexose-ATP-kinase and the ability of the cells to take up hexoses were measured. Nine mutants of group I in Table 1 exhibited hexose-ATP-kinase activity which was comparable to that of wild-type cells, as shown for YGS-B22 in Table 2.
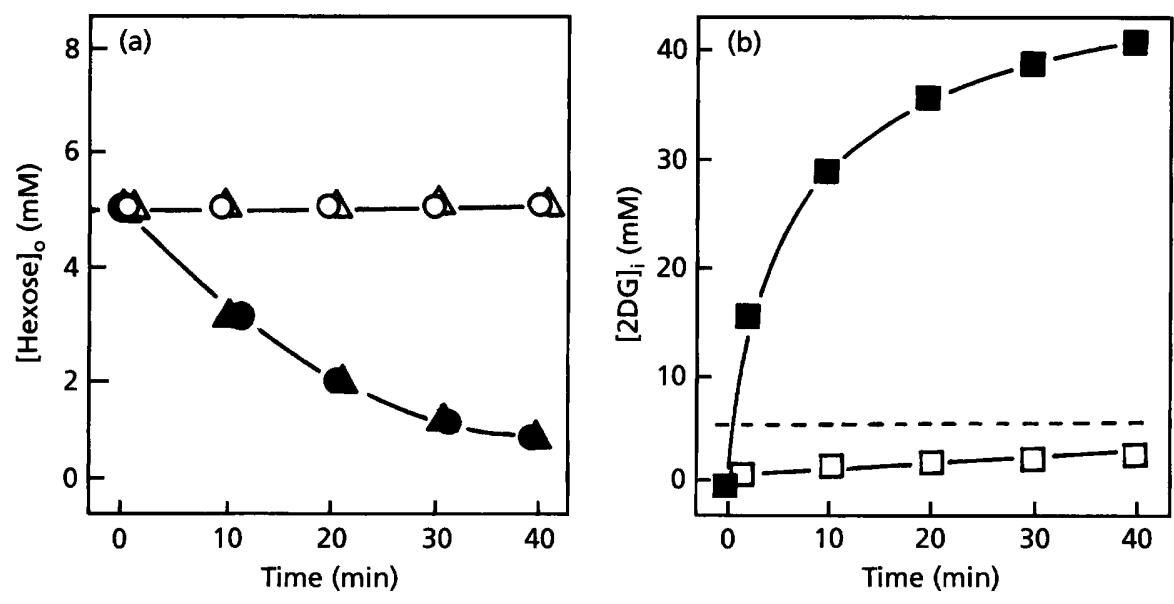

Fig. 1. Hexose transport in SCh. pombe wild-type and the mutant YGS-B22. (a) Uptake of D-glucose and D-fructose determined as sugar consumption from cell suspensions; (b) intracellular accumulation of 2DG (the broken line corresponds to the external 2DG concentration). Initial external hexose concentration [(Hexose) $)_{0}$, $5 \mathrm{mM}$; filled symbols, wild-type cells; open symbols, YGS-B22 cells; circles, D-glucose; triangles, D-fructose; squares, 2DG. 
The two colonies of group III of Table 1 displayed a rather unusual phenotype: no growth on either D-glucose or D-fructose, and yet high sensitivity to $2 \mathrm{DG}(2 \mathrm{DG})$ when grown on D-gluconate. One of them, GPD, was further biochemically characterized: its hexose-ATPkinase activity and transport capacity were significantly higher than those of the wild-type; however, the glucose6-phosphate dehydrogenase activity was virtually eliminated (unpublished results). Hence, the GPD mutant was a glucose-6-phosphate-dehydrogenase-deficient mutant. Its failure to grow on D-glucose was due to its inability to synthesize pentose phosphates via the oxidative branch of the pentose phosphate cycle. The reductive part of the pentose phosphate cycle is obviously not effective enough to supply wild-type cells with pentose phosphates for nucleotide synthesis, as manifested by their slow growth on glycerol and lack of growth on ethanol (data not shown).

\section{Phenotypic characteristics}

The nine mutants of group I with unaffected hexose-A TPkinase activity met the criteria for glucose transport deficiency: all were unable to take up either D-glucose or D-fructose, as shown for the mutant YGS-B22 in Fig. 1'a). Hence, none of the mutants accumulated 2DG, a nonmetabolizable analogue of D-glucose (Fig. 1b). Of these transport-deficient mutants, strain YGS-B22 was chosen for further genetic analysis.

\section{Genetic analysis of the YGS (yeast glucose symporter) mutants}

The transport-deficient mutant YGS-B22 was first crossed with the auxotrophic mutant $S c b$. pombe $\left(\right.$ leu $\left.1-32 b^{+}\right)$in order to introduce a marker for complementation experi-
Table 3. Phenotypes of wild-type Sch. pombe and the two glucose-transport-deficient mutants used for complementation

Glc, D-glucose; Fru, D-fructose; Glt, D-gluconate. All three strains have the $\mathrm{h}^{-}$mating type.

\begin{tabular}{|llcc|}
\hline Strain & Growth & $\begin{array}{c}2 \mathbf{D G}^{\mathbf{R}} / \\
2 \mathbf{D G}^{\mathbf{S}}\end{array}$ & $\begin{array}{c}\text { Leucine } \\
\text { phenotype }\end{array}$ \\
\hline Wild-type $972 \mathrm{~h}^{-}$ & $\mathrm{Glc} / \mathrm{Fru}^{+} \mathrm{Glt}^{+}$ & $2 \mathrm{DG}^{\mathrm{s}}$ & $\mathrm{Leu}^{+}$ \\
Mutant YGS-4 & Glc/Fru $\mathrm{Glt}^{+}$ & $2 \mathrm{DG}^{\mathrm{R}}$ & Leu $^{-}$ \\
Mutant YGS-5 & Glc/Fru Glt & $2 \mathrm{DG}^{\mathrm{S}}$ & Leu $^{-}$ \\
\hline
\end{tabular}

ments; this double mutant was designated YGS-B25. Furthermore, to eliminate unwanted (and undefined) mutations, the YGS-B25 mutant was further back-crossed three times with the wild-type strain $975 \mathrm{~h}^{+}$, and, after each crossing, selected for leucine auxotrophy and transport-deficiency by free spore-analysis on screening plates (see Methods). The back-crossing experiments revealed that resistance to $2 \mathrm{DG}$ is not necessarily linked to transport deficiency. Consequently, two back-crossed strains were isolated: YGS-4, which was 2DG-resistant $\left(2 \mathrm{DG}^{\mathrm{R}}\right)$ and $Y G S-5$ which was $2 \mathrm{DG}$-sensitive $\left(2 \mathrm{DG}^{\mathrm{S}}\right)$ : see Table 3. The two strains did not take up either Dglucose (Fig. 2a) or D-fructose (not shown), nor did they accumulate 2DG; however, there was a very slow but measurable uptake of 2DG in strain YGS-5 (Fig. 2b).

Tetrad analysis was performed following the crossing of both strains YGS-4 and YGS-5 with the wild-type $S c h$. pombe $975 \mathrm{~h}^{+}$. Spores from 55 asci were separated and screened on screening plates with or without $\mathrm{D}^{-}$ glucose/D-fructose, and with or without leucine. Both the
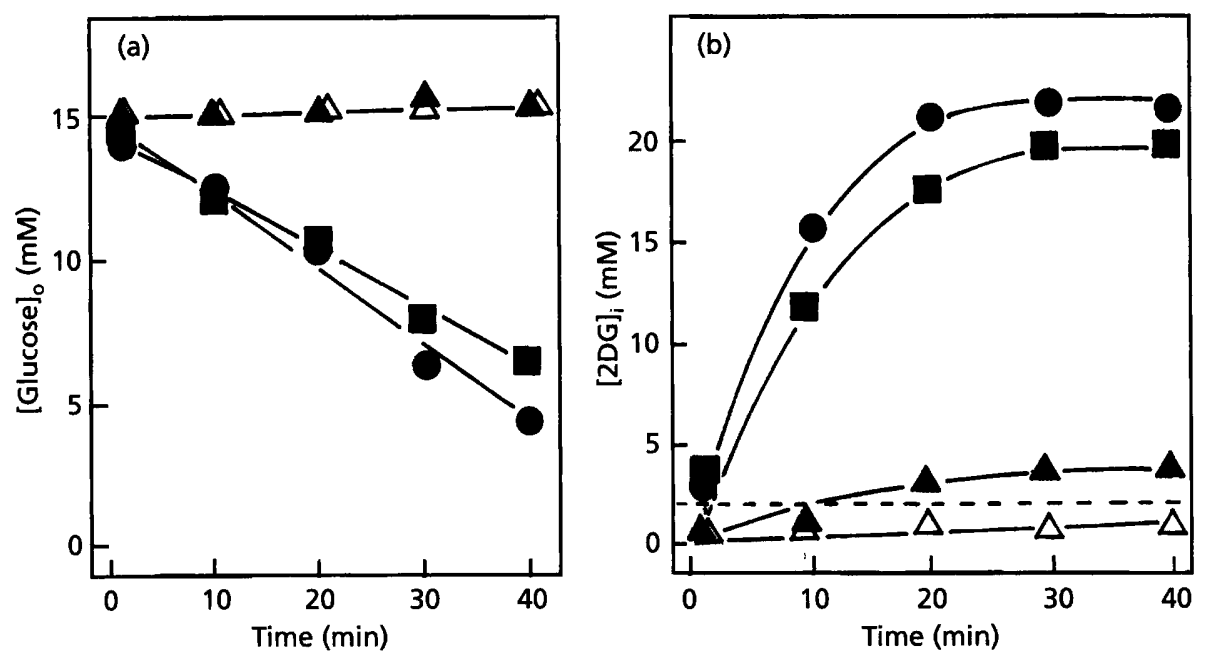

Fig. 2. Hexose transport in Sch. pombe wild-type, the mutant YGS-5 and the complemented strains YGS-5-G7 and YGS-5G12. (a) Uptake of D-glucose (15 mM) determined as glucose consumption from cell suspensions; (b) intracellular accumulation of 2DG ( $2 \mathrm{mM}$, the broken line corresponds to the external 2DG concentration). Circles, wild-type cells; filled triangles, YGS-5 cells; open triangles, YGS-4 cells; squares, YGS-5-G7 cells; virtually identical results were obtained with YGS-5-G12 cell suspensions (not shown). 


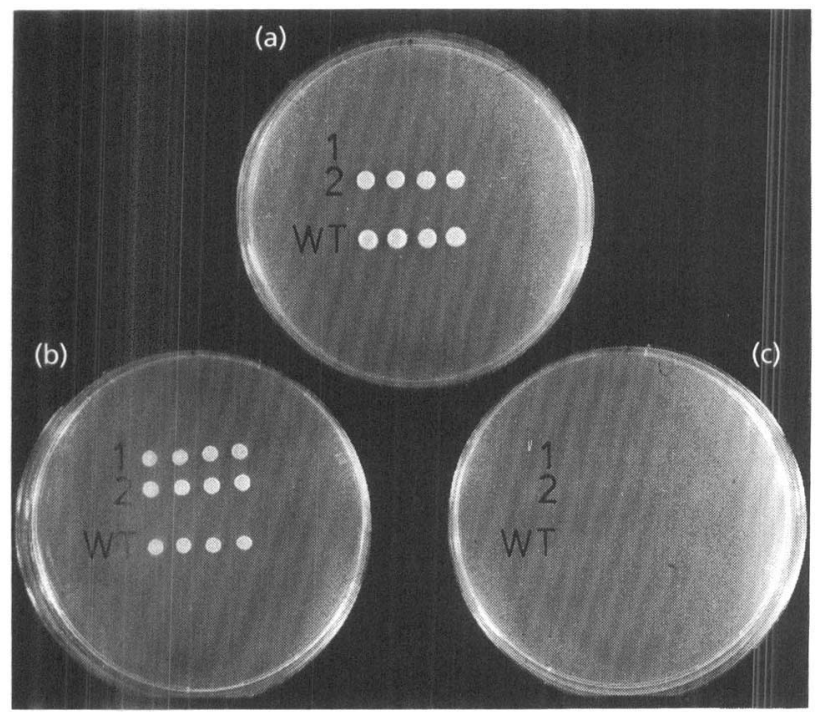

Fig. 3. Phenotype of the clones YGS-4-G12 (1) and YGS-5-G12 (2) as compared with wild-type Sch. pombe $972 \mathrm{~h}^{-}$(WT). (a) Growth on glucose; (b) growth on gluconate; (c) growth on gluconate $+2 D G$. Virtually identical results were obtained with clones YGS-4-G7 and YGS-5-G7 (not shown).

transport deficiency and the leucine auxotrophy segregated according to Mendel's law. However, the segregation of the $2 \mathrm{DG}$ resistance of strain $Y G S-4$ was not
$2: 2$ but random $\left(2 \mathrm{Glc} / \mathrm{Fru}^{+} 2 \mathrm{DG}^{\mathrm{S}}: 1 \mathrm{Glc} / \mathrm{Fru}^{-} 2 \mathrm{DG} \mathrm{G}^{\mathrm{S}}: 1\right.$ $\mathrm{Glc} / \mathrm{Fru}^{-} 2 \mathrm{DG}^{\mathrm{R}}$ ). This confirms the conclusion from the free-spore analysis that 2DG-resistance and transport deficiency are not co-segregated.

Stable diploid cells for complementation experiments were obtained by crossing strain $Y G S-4$ with the mutant deficient in the early meiotic phase, mat2-B102 lys 1-131. Of a population of 109 diploid colonies tested, all exhibited the wild-type growth phenotype. Thus, the genetic analysis of the two D-glucose-transport-deficient mutant strains, YGS-4 and YGS-5, derived from $S c h$. pombe $972 \mathrm{~h}^{-}$proved that the mutation was nuclear, monogenic and recessive.

\section{Molecular cloning of the glucose symporter gene}

By complementation of strain $Y G S-5$ with a genomic gene bank of $S c h$. pombe, $C V 13$ (Beach et al., 1982), two clones, $Y G S-5-G 7$ and $Y G S-5-G 12$, were isolated which had regained the wild-type growth and transport phenotype (Fig. 3). Correspondingly, the uptake of D-glucose (Fig. 2a) and the accumulation of 2DG (Fig. 2b) were restored. The stability test proved that the complementation was due to the function of the genomic DNA inserts $G 7$ and $G 12$ in YEp13. In addition, backtransformation experiments confirmed that each of the two DNA inserts contained the complementing information. (a)

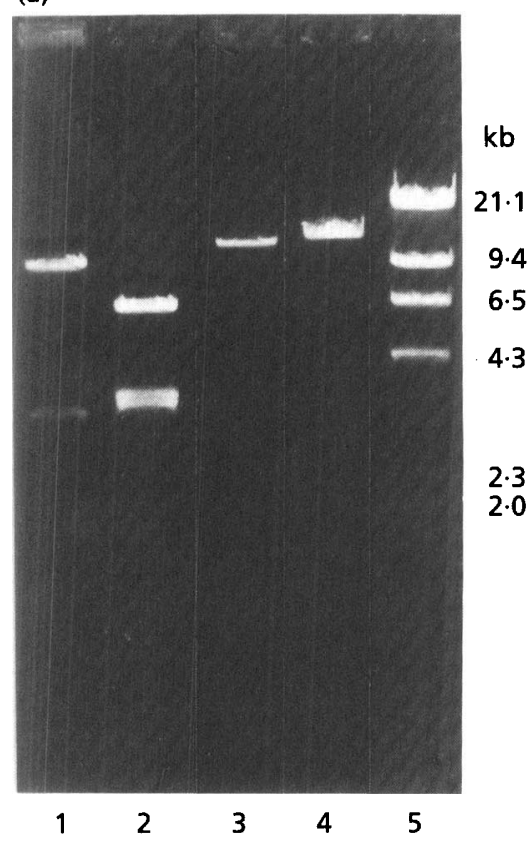

(b)

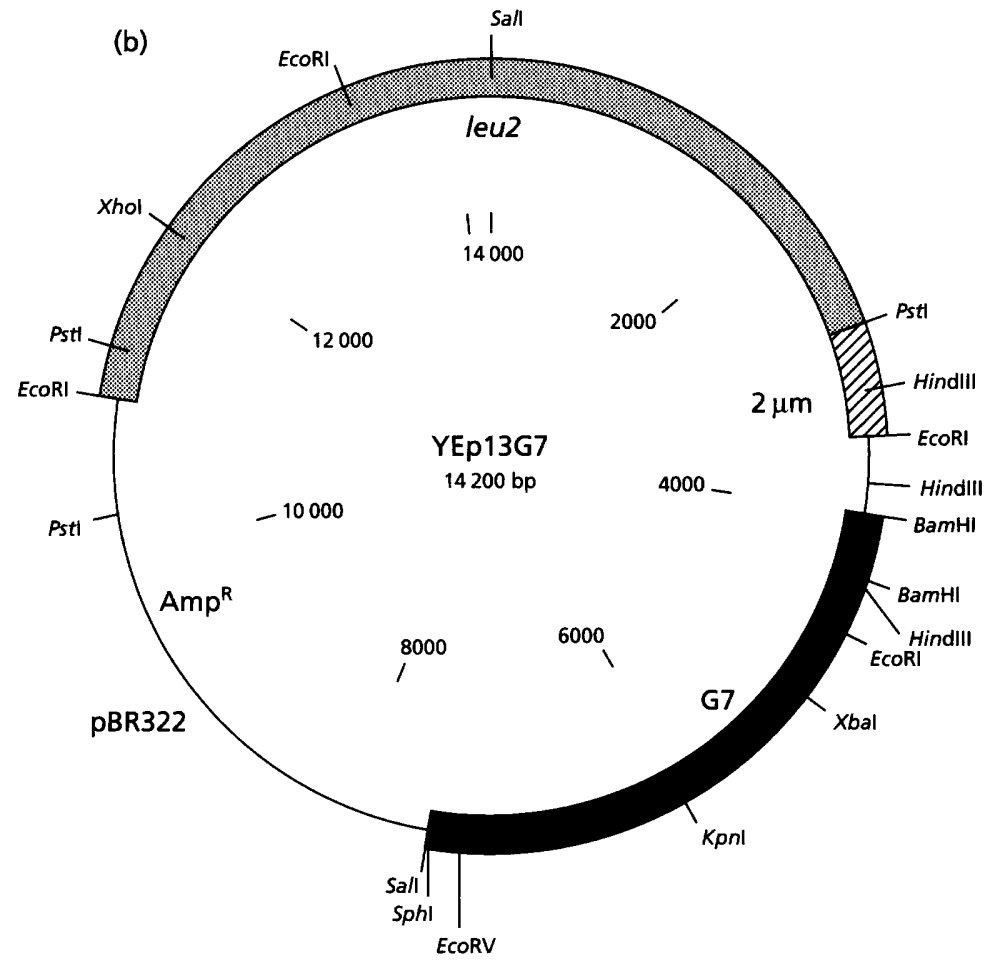

Fig. 4. Restriction analysis (a) and a scheme (b) of the plasmid YEp13-G7. In (a), fragment separation was carried out in a $0.7 \%$ agarose gel after $4 \mathrm{~d}$ growth at $30^{\circ} \mathrm{C} ; 1, \mathrm{BamHI} / \mathrm{Sphl} ; 2, \mathrm{BamHI} / \mathrm{Sall}$ (the lower band is a doublet); 3, Sphl; 4, BamHI; 5, $\lambda$ DNA digested with HindlII. 
(a)

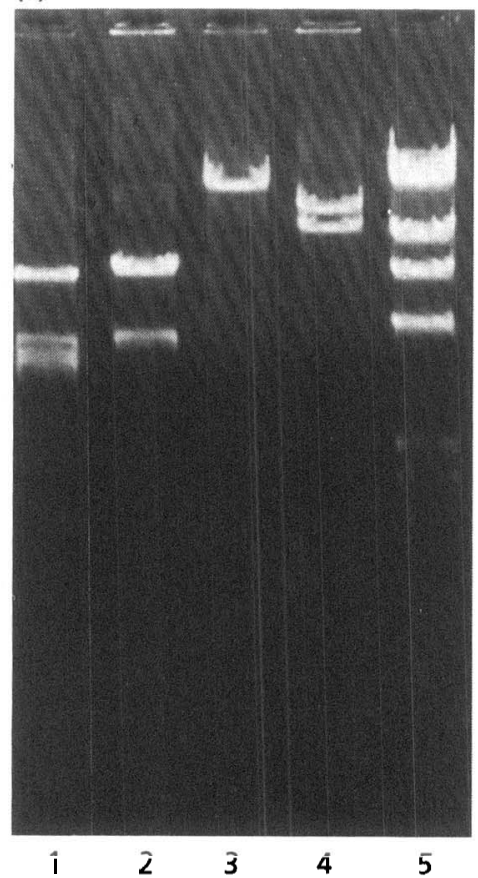

(b)

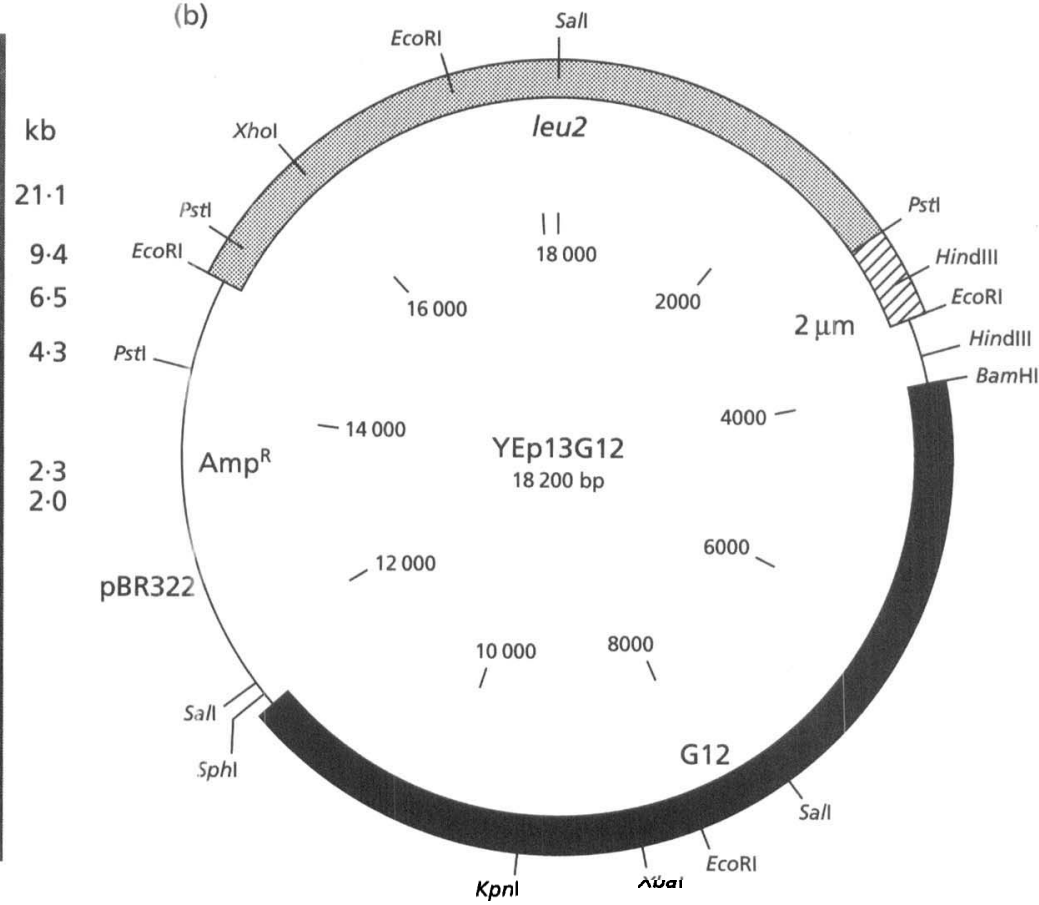

Fig. 5. Restriction analysis (a) and a scheme (b) of the plasmid YEp13-G12. In (a), fragment separation was carried out in a $0.7 \%$ agarose gel after $4 \mathrm{~d}$ growth at $30^{\circ} \mathrm{C} ; 1$, BamHI/Sall; 2 , Sall (the lower band is a doublet); $3, B a m H I ; 4, H i n d I I I ; 5, \lambda$ DNA digested with HindIII.

The sizes of the two genomic DNA inserts, $4 \mathrm{~kb}(\mathrm{G} 7)$ and $7.5 \mathrm{~kb}(\mathrm{G} 12)$ within the Bam HI and SalI restriction sites, were determined by restriction analysis of the plasmids YEp13-G7 (Fig. 4) and YEp13-G12 (Fig. 5), respectively. The genomic insert in YEp13-G12 contained an additional Sall restriction site, giving two fragments of approximately 3.4 and $4.1 \mathrm{~kb}$ (Fig. 5). Two additional restriction sites, EcoRI and $X b a \mathrm{I}$, were found both in $\mathrm{G}$ ? $(4 \mathrm{~kb})$ and the $4 \cdot 1 \mathrm{~kb}$ fragment of $\mathrm{G} 12$, suggesting that the two DNA fragments are conformable.

Subclones of the two genomic DNA inserts, G7 (4 kb) and the $4.1 \mathrm{~kb}$ fragment of $\mathrm{G} 12$, were used as probes in Northern blots with total $S c h$. pombe RNA to determine the size of the glucose symporter mRNA transcript. The two probes detected signals of $3.7 \mathrm{~kb}$ in both the wildtype and the complemented strains (unpublished results), strongly supporting their proposed conformity. These results provide substantial evidence that with the two DNA fragments, the complete structural symporter gene has been cloned. Sequencing of the two fragments is in progress.

Two other clones, YGS-4-G7 and YGS-4-G12, were isolated by transforming strain YGS-4 with YEp13-G7 and YEp13-G12, following their propagation in E. coii $\mathrm{DH} 5 \alpha$. These two clones did not grow on D-glucose, although they regained the $2 \mathrm{DG}$ sensitivity of the wildtype (see Fig. 3). This indicates that the mutant YGS-4 exhibits, in addition to a mutation in the structural symporter gene, another mutation in a different locus on the Sch. pombe genome. Whether or not the glucose symporter gene is under genetic regulation will be further investigated.

\section{ACKNOWLEDGEMENTS}

We are indebted to Drs J. Kohli and P. Munz, University of Bern, Switzerland, for supplying us with the Sch. pombe strains and for helpful discussion during the work. E. coli strain $\mathrm{DH} 5 \alpha$ was kindly provided by Dr B. Persson, University of Umeå, Sweden. We thank Dr K.-D. Entian, University of Frankfurt, Germany, for letting us use the micromanipulator, and $\mathrm{Dr}$ P. Nurse, University of Oxford, UK, for sending us the genomic Sch. pombe gene bank. Dr H.-C. Lichtenberg-Fraté, of the authors' laboratory, carried out some control experiments to Figs 4 and 5 ; her contribution is greatly appreciated. This work was supported by the Deutsche Forschungsgemeinschaft, grant no. Ho 555/12-4.

\section{REFERENCES}

Beach, D., Piper, M. \& Nurse, P. (1982). Construction of a Schizosaccharomyces pombe gene bank in a yeast bacterial shuttle vector and its use to isolate genes by complementation. Mol \& Gen Genet 187, 326-329.

Ciriacy, M. (1976). cis-Dominant regulatory mutations affecting the formation of glucose-repressible alcohol-dehydrogenase in Saccharomyces cerevisiae. Mol \& Gen Genet 145, 327-333.

Gutz, H., Heslot, H., Leupold, U. \& Loprieno, N. (1974). Handbook of Genetics, vol. 1. New York \& London: Plenum Press.

Gygax, A. \& Thuriaux, P. (1984). A revised chromosome map of the fission yeast Schizosaccharomyces pombe. Curr Genet 8, 85-92. 
Heyer, W.-D., Sipiczki, M. \& Kohli, J. (1986). Replicating plasmids in Schizosaccharomyces pombe: improvement of symmetric segregation by a new genetic element. Mol Cell Biol 6, 80-89.

Hoever, M., Milbradt, B. \& Höfer, M. (1992). D-Gluconate is an alternative growth substrate for cultivation of Schizosaccharomyces pombe mutants. Arch Microbiol 157, 191-193.

Höfer, M. \& Nassar, F. R. (1987). Aerobic and anaerobic uptake of sugars in Schizosaccharomyces pombe. J Gen Microbiol 133, 2163-2172.

Ito, H., Fukuda, Y., Murata, K. \& Kimura, A. (1983). Transformation of intact yeast cells treated with alkali cations. J Bacteriol 152, $163-168$.

Lang, G. \& Michal, G. (1974). D-Glucose-6-Phosphat und DFructose-6-Phosphat Bestimmung mit Glucose-6-PhosphatDehydrogenase und Phosphoglucose-Isomerase. In Methoden der enzymatischen Analyse II, pp. 1283-1287. Edited by H. U. Bergmeyer. Weinheim: Verlag Chemie.

Lennox, E. S. (1955). Transduction of genetic linked characters of the host by bacteriophage P1. Virology 1, 190-206.

Mahlberg, D., Höfer, M. \& Täuber, A. (1985). Sugar transport and hexose-ATP-kinase activity in a 2-deoxy-D-glucose tolerant mutant of the yeast Rbodotorula glutinis. J Gen Microbiol 131, 479-485.

Maniatis, T., Fritsch, E. F. \& Sambrook, J. (1982). Molecular Cloning: a Laboratory Manual, pp. 25-39. Cold Spring Harbor, NY: Cold Spring Harbor Laboratory.

Megnet, R. (1965a). Screening of auxotroph mutants of Schizosaccharomyces pombe with 2-deoxy-D-glucose. Mutat Res 2, 328-331.
Megnet, R. (1965b). Effect of 2-deoxyglucose on Schizosaccharomyces pombe. J Bacteriol 90, 1032-1035.

Milbradt, B. \& Höfer, M. (1990). Isolation and characterization of a Rbodotorula glutinis mutant defective in glucose transport. $J$ Gen Microbiol 136, 1961-1965.

Milbradt, B. \& Höfer, M. (1991). Hexose-transport-deficient mutant of Schizosaccharomyces pombe: phenotypes and genetics. In Workshop on Yeast Transport and Energetics (Serie Universitaria 264), pp. 64-65. Edited by A. Rodríguez-Navarro \& R. Lagunas. Madrid: Fundación Juan March.

Milbradt, B., Höfer, M. \& Lichtenberg-Fraté, H.-C. (1993). Cloning of the glucose symporter by complementation of a transportdeficient mutant of Schizosaccharomyces pombe. In Metabolic Compartmentation in Yeast (Abstracts of ISSY 16, Arnhem, The Netherlands), pp. 180-182. Edited by W. A. Scheffers \& J. P. van Dijken. The Hague: Pasmans.

Moreno, S., Klar, A. \& Nurse, P. (1991). Molecular genetic analysis of fission yeast Schizosaccharomyces pombe. Methods Enzymol 194, 795-823.

Niemietz, C., Hauer, R. \& Höfer, M. (1981). Active transport of charged substrates by a proton/substrate cotransport system. Biochem J 194, 433-441.

Rose, M. D. (1987). Isolation of genes by complementation in yeast. Methods Enzymol 152, 481-511.

Received 20 January 1994; revised 31 March 1994; accepted 20 April 1994. 